\author{
Selvinaz Saçan \\ Aile ve Sosyal Politikalar İl Müd.ğü, skuzucu@gmail.com, Aydin-Turkey \\ İsmihan Artan \\ Hacettepe University, ismihan@hacettepe.edu.tr, Ankara-Turkey \\ Neşe Erol \\ Ankara University, erol@medicine.ankara.edu.tr, Ankara-Turkey \\ Zeynep Şimşek \\ Harran University, zsimsek@harran.edu.tr, Sanliurfa-Turkey
}

\author{
http://dx.doi.org/10.12739/NWSA.2014.9.2.E0019
}

\title{
KURUM BAKIMINDAN AİE YANINA DÖNDÜRÜLEN 6-18 YAŞ ÇOCUKLARIN DUYGUSAL VE DAVRANIŞ SORUNLARI
}

\section{ÖZET}

Bu araştırmada, çoklu bilgi kaynakları kullanılarak kurum bakımından Sosyal ve Ekonomik Destekle (SED) ailesi yanına döndürülen 618 yaşları arasındaki çocukların davranış ve duygusal sorunlarını, koruma altında olmayıp SED ile ailesi yanında ve yuva-yurtta büyüyen çocuklarla karşılaştırılmıştır. Araştırmanın örneklemini, Kütahya ìl Sosyal Hizmetler Müdürlüğü bünyesinde 6-18 yaşları arasındaki korunma altında olup aile yanına döndürülen 37, ayni nakdi yardımla ailesi yanında kalan 81 ve yuva-yurtta büyüyen 65 çocuk olmak üzere toplam 183 çocuk oluşturmuştur. Veri toplamada, Aile Bilgi Formu, CBCL/6-18, TRF/618 ve YSR/11-18 ölçekleri kullanılmıştır. Bulgular incelendiğinde, aile yanına döndürülen çocukların sorun davranışlarının diğer iki gruba göre daha fazla olduğu saptanmıştır ( $P<0.05)$.

Anahtar Kelimeler: Aile Yanına Dönüş, Kurum Bakımı, Bakım Verenler, Gençler, Davranış Sorunları

\section{PROBLEM BEHAVIORS OF 6-18 YEAR OLD CHILDREN WHO HAVE BEEN MOVED FROM INSTITUTIONS TO THEIR BIOLOGICAL FAMILIES}

\section{ABSTRACT}

The aim of this study was to determine the problem behaviors of children aged 6-18, who have been moved from institutions to their biological families with the financial aid. The data were collected from caregivers, teachers and youth informants and compared of the same-aged children grown up by their families with the financial aid not being under protection and those who were grown up in institutional care. The sample of this study consisted of 37 children who were under protection and sent back to their families, 81 children who stayed with their families and 65 children who were grown up in institutional care. The total number of children was 183. Family Report Form, CBCL/6-18, TRF/618 and YSR/11-18 were used for data collection. The children who have been moved from institutions to their biological families had higher problem behaviors than the children who stayed with their families and those who grew up in institutional care $(P<0.05)$.

Keywords: Re-Unification to the Family, Institution Care, Caregivers, Youths, Behavioral Problems 


\section{GIRIŞ (INTRODUCTION)}

Çocukların sağlıklı büyümesi ve gelişmesi, anne-babalık donanımı ve doğum öncesinden başlayarak onlara sunulacak doğru sağlık bakımı, bebeğin ona bakan kişilerle kurduğu güvenli bağlılık, yeterli ve dengeli beslenme, korunma ve eğitimle mümkündür.

Ancak yoksulluk, aile içi sorunlar, anne-babada bedensel, ruhsal ya da zihinsel yetersizlikler, annenin ya da babanın ölümü, ihmal ya da istismar, ergen evlilikleri ya da evlilik dışı doğumlar sonucu terkler gibi pek çok nedenle anne-babalık görevleri yetersiz kalabilmekte ve çocuk korumasız hale gelebilmektedir. Bu durumda çocuklar devlet tarafından korunma altına alınarak farklı bakım modellerinde büyütülmektedir [13, 14 ve 23].

Ülkemizde koruma gereksinimi altındaki çocuklarla ilgili yasal düzenlemeler incelendiğinde; 2828 sayılı Sosyal Hizmetler Çocuk Esirgeme Kurumu kanunu ile korunmaya muhtaç çocuklara "Çocuk Yuvaları ve Yetiştirme Yurtları" aracılığı ile hizmet verilmesi öngörülmüştür [27]. 2005 yılında yapılan değişiklikle 0-18 yaş çocuklar için "Çocuk Evleri" modeline geçilmiştir. Korunma gereksinimi olan veya suça sürüklenen çocukların korunması amacıyla 5395 sayılı yasal düzenleme ile bakım tedbiri uygulama görevi Sosyal Hizmetler Çocuk Esirgeme kurumuna verilmiştir [39]. 2011 yılında çıkarılan 633 sayılı Kanun Hükmünde Kararname ile Aile ve Sosyal Politikalar Bakanlığı kurulmuş ve (Mülga) Sosyal Hizmetler Çocuk Esirgeme Kurumu'nun işleri Bakanlığa devredilmiştir. Çocuklara yönelik hizmetler Aile ve Sosyal Politikalar Bakanlığına bağlı çocuk Hizmetleri Genel Müdürlüğü tarafından yürütülmeye başlanmıştır.

Türkiye'de çocuk yuvalarında ve yetiştirme yurtlarında büyütülen çocuklarla ilgili yapılan pek çok araştırmada, yuva ve yurtta büyüyen çocukların ailesi yanında yaşayan çocuklara göre fiziksel gelişimlerinin geri olduğu, uyum düzeylerinin daha düşük olduğu ve bu çocukların aile yanında yaşayan çocuklara oranla daha sorunlu oldukları belirlenmiştir [25, 26 ve 31]. Koruyucu aile yanında bakılan çocukların duygusal ve davranış sorunlarına yönelik Üstüner ve arkadaşları tarafından yapılan araştırmada ise sorun davranışların görülme sıklığı; koruyucu aile yanında bakılan çocuklarda o12.9, biyolojik aile yanında kalan çocuklarda \%9.7, kuruluşlarda yaşayan çocuklarda ise \%43.5 olarak saptanmıştır [32].

2005 yılında "Çocuk Koruma Sisteminin Değerlendirilmesi" amacıyla yürütülen araştırmada, çocukların o71,6 ile "ekonomik ve sosyal sorunlar", 25,6'sının ise terk nedeniyle koruma altına alındığı saptanmıştır. Yuvalarda büyüyen çocukların \%59,6'sı ile yurtlarda büyüyenlerin o53,4'ünün gerekli ortam ve destek sağlandığında biyolojik ebeveynlerinin yanına dönebilecek koşullara sahip olduğu saptanmıştır [39].

1995'te Türkiye tarafından imzalanan ve 22184 sayılı Resmi Gazete'de yayınlanarak yasal bir belge konumuna gelen Birleşmiş Milletler Çocuk Hakları Sözleşmesi'nde "çocuğun yüksek yararına aykırılığı belirlenmediği sürece çocuk kendi ana-babasıyla birlikte yaşama hakkına sahiptir" denilmektedir [20].

Çocuk Koruma Sisteminin Değerlendirilmesine yönelik yapılan araştırma sonuçlarına göre; yoksulluk nedeniyle kuruluş bakımına verilen çocukların "Aileye Destek ve Aileye Geri Dönüş Projesi" kapsamında desteklenmesi sağlanarak Mart 2014 tarihine kadar 10.079 çocuk aile yanına döndürülmüştür [39 ve 40].

\section{2. ÇALIŞMANIN ÖNEMİ (RESEARCH SIGNIFICANCE)}

Literatürde kuruluşlarda yaşayan çocukların duygusal ve davranış sorunlarına yönelik çalışmalar yer alırken, kurum deneyiminden sonra ailesi yanına döndürülen çocukların ruh sağlığına ilişkin araştırma yok 
denecek kadar azdır. Bu çalışmada, aile yanına döndürülen çocukların sorun davranışlarının ailesi yanında kalan ve yuva yurtta büyüyen çocuklardan yüksek çıkması, sosyal ve ekonomik destekle aile yanına döndürülme hizmetinin planlama ve uygulama sürecinde yapılması gerekenler için yol göstericidir. Öte yandan, araştırma verisinin annebaba, bakım verenler, öğretmenler ve gencin kendisi gibi çoklu bilgi kaynaklarından alınmış olması yanlılık düzeyini en aza indirmektedir.

\section{AILE YANINA DÖNÜS (RE-UNIFICATION WITH THE BIRTH FAMILY)}

Kuruluş bakımından aileye dönüş, çocuğun, ailesinin ve bakım veren kişilerin yaşamında önemli değişimlere neden olmakta, yer değişikliği çocuklar için oldukça travmatik bir yaşantı haline gelebilmektedir. Çocukların birçoğu, birkaç kez yer değişikliği yaşayabilmekte ve kendine güven duygusu ile öz sayglları bu durumdan olumsuz etkilenebilmektedir. Açıklama yapılmadan yapılan yer değişikliklerinden dolayı çocukların yetişkinlere güven duymaları zorlaşmaktadır. Bu nedenle çocuğun kuruluş bakımından aile yanına dönme süreci çok dikkatli planlanmalı, çocuk ve aile bu sürece hazırlanmalıdır. Çocuk, aile yanına döndükten sonra da desteklenmeli ve takip edilmelidir [7].

Browne, küçük çocukların kuruluş bakımından alınıp aile yanına yerleştirilmesi sürecinde 10 basamaklı bir model oluşturmuştur. Modelin orijinal grafiği Şekil 1'de verilmiştir.

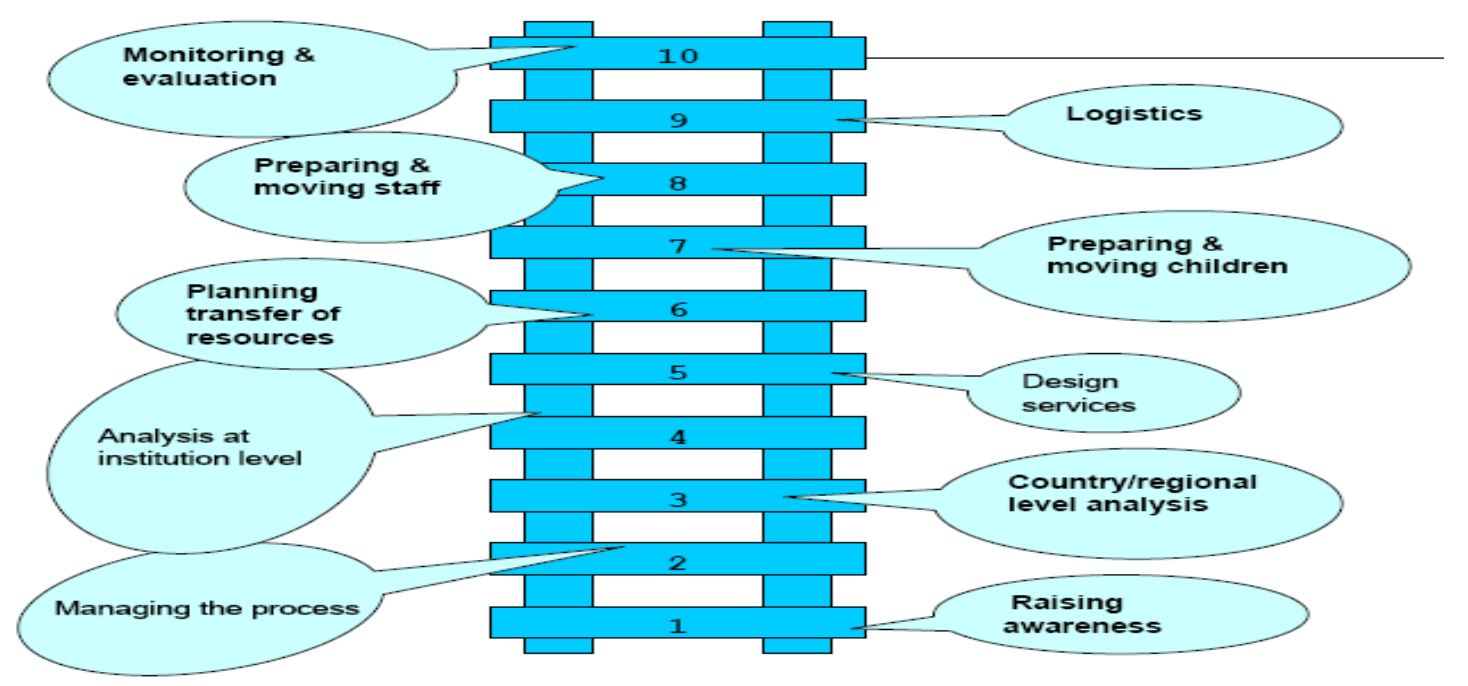

Şekil 1. Kurum bakımından alma basamakları

(Figure 1. Take Steps from institution care)

Browne, K. (Çev. Altınoğlu Dikmeer, 亡̇.) [5].

1. Basamak: Farkındalığı Arttırmak

2. Basamak: Süreç Yönetimi

3. Basamak: Ülke/bölge Analizi

4. Basamak: Kuruluş Analizi

5. Basamak: Hizmetlerin Tasarlanması

6. Basamak: Kaynakların Dönüştürülmesinin Planlanması

7. Basamak: Çocukların Hazırlanması ve Taşınması

8. Basamak: Elemanların Hazırlanması ve Taşınması

9. Basamak: Geri Hizmetler

10.Basamak: İzleme ve Değerlendirme

Çocukları kuruluş bakımından alma sürecinde, süreçle ilgili çocuklar, ebeveynler, kuruluş personeli, halk ve hükümetin, kuruluş 
bakımının olumsuz etkileri ve çocukların ailelerinin yanına döndürülmesinin amacı hakkında bilgi sahibi olmaları gereklidir.

Kuruluş bakımına alınan çocukların sayısı, yaşı, cinsiyeti, kuruluşa geliş nedenleri, sağlık ve öğrenim durumu, kuruluşa bırakılış şekli, kuruluşta bakılan çocukların ortalama kalış süreleri, biyolojik ebeveynlerinin son durumlarına ilişkin bilgilerin toplanması kurum bakımı altındaki çocukların mevcut durumlarının ortaya çıkarılması açısından önemlidir. Çocukların kuruluştan ayrılma nedenleri, kuruluştan ayrılan çocukların gönderildikleri yerler, kuruluşların bulunduğu illerin sosyo-kültürel ve demografik özellikleri ve kuruluşlara ait çocuk-personel sayısı ve niteliği gibi bilgiler ile kaynak ve personel ihtiyacının belirlenmesi çocuklara sunulacak yeni hizmet modellerinin planlanmasında yol gösterici olacaktır. Anne-bebek hizmetlerinin güçlendirilerek kuruluşa başvurunun önlenmesi, korunma ihtiyacı olan çocuklar için; koruyucu aile, evlat edinme, akraba yanında bakım gibi alternatif hizmetlere öncelik verilmesi ve var olan kuruluş binalarının yeni hizmetler için planlanması oldukça önemlidir.

Çocuğun kuruluştan ayrılmaya yönelik tutumu yeni yaşam biçimine uyumunu etkileyebilir. Bu nedenle çocuklar değişiklik öncesinde çok iyi hazırlanmalıdır. Çocuğu hazırlama, üç büyük bileşeni kapsar. Bunlar; yetişkinlerle güven ilişkisi oluşturma, gelişimsel gecikmeleri iyileştirme, davranış problemlerini belirleme ve çocuğu yeni yere alıştırmadır.

Çocuğa kuruluştan ayrılık nedeni, şekli, olası zamanı yaşına uygun şekilde olabildiğince açık anlatılmalı, gideceği yer (aile, kuruluş vb) önceden tanıtılmalıdır [5].

Çocuğu yeni yerine en iyi şekilde hazırlamak amacıyla yapılacak olan bireysel programda, çocuğun geçmişi, ihtiyaçları ve dileklerine ait net bir resmin oluşturulması gereklidir [7].

Her yeni yerleştirmeden sonra ilk üç ay içinde ve sonraki iki yıl boyunca altı ayda bir ziyaretler düzenlenerek çocuk ve aile izlenmelidir [5].

Aile yanına dönüş sürecinde kontrol edilmesi gereken hususlar şunlardır:

- Çocuğun biyolojik ebeveynleri ile ilgili bilgisinin olup olmadığı,

- Çocuk kurum bakımına alınmadan önce aile içinde ihmal, istismar gibi herhangi bir olayın olup olmadığı,

- Çocuğun döneceği aile üyelerine ait adli kaydın olup olmadığı,

- Çocuğun döneceği evin fiziksel koşullarının çocuğun minimum fiziksel ihtiyaçlarını karşılamaya yeterli olup olmadığı,

- Ailenin çocuğu eve götürmeye istekli olup olmadığı,

- Çocuk için bireysel bakım planı geliştirilip geliştirilmediği,

- Çocuk ve aile için bireysel plan ile birlikte paket program geliştirilip geliştirilmediği,

- Çocuk ve ebeveyni arasında sağlıklı bir bağ gözlenip gözlenmediği,

- Çocuğun dönüşü ile ilgili bir hazırlık süreci başlatılıp başlatılmadığı,

- Hazırlama sürecinden sorumlu meslek elemanlarına göre, hem ailenin hem de çocuğun dönüş sürecine hazır olup olmadığı,

- Kalıcı dönüş gerçekleşmeden önce çocuğun en az 3 kez geçici olarak evinde yatılı olarak kalıp kalmadığı,

- Dönüş sürecine, ebeveynler ve ailenin geri kalan üyelerinin hazır olup olmadığı,

- Yaş ve bireysel özelliklerine uygun olarak çocuğa dönüş sürecinin nasıl ve ne zaman olacağının anlatılıp anlatılmadığı,

- Eve dönüş ile ilgili karara çocuğun katılımının sağlanıp să̆lanmadı ̆̆ı, 
- Dönüş sürecinden sonra çocuğun mevcut kaldığı yer ile en azından bir süre bağlantısını sürdürebilmesi ile ilgili bir düzenleme yapılıp yapılmadı ğı,

- Özel eğitim ihtiyacı olan çocuklarla ilgili mevcut durumda aldığı özel eğitim desteğinin devam etmesi ile ilgili bir düzenleme yapılıp yapılmadığı,

- Dönüş ile birlikte çocuğun okulunun değişmesi gerektiğinde çocuk için uygun okul planlamasının yapılıp yapılmadığı,

- Çocuğun ve ailenin kayıtlı olduğu sağlık birimi olup olmadığı,

- Çocuğun devam eden tıbbi ihtiyaçları olduğunda tıbbi ve ilaç tedavisinden nasıl faydalanacağı kontrol edilmelidir [7].

Kuruluş bakımından aile yanına dönüş yaşayan çocukların yeni yaşamlarına uyum sağlayıp, sağlayamadıklarını değerlendirmede şu kriterler göz önüne alınmalıdır:

- Çocuğun yeni ortama uyum sağlayamamasından kaynaklı problemlerinin olup olmadığı,

- Çocuğun sağlığı ve gelişiminde iyileşmenin olup olmadığı,

- Çocuğun gelişimi ve mutluluğu ile ilgili profesyonellerin düşünceleri,

- Çocuğun değişen yaşamı ile ilgili kendi düşünceleri [7].

\section{YÖNTEM (METHOD)}

\subsection{Araştırmanın Örneklemi (The Sample)}

Araştırma Mart-Aralık 2007 tarihleri arasında Kütahya'da aile yanına döndürülen 37, ayni naki yardımla ailesi yanında kalan 81 ve yuva-yurtta kalan 65 çocukla yürütülmüş ve üç grup karşılaştırılmıştır.

\subsection{Veri Toplama Araçları (Data Collection Tools)}

Araştırma verisi anne-babalar/bakımverenler, öğretmenler ve gençler olmak üzere çoklu bilgi kaynaklarından elde edilmiştir. Araştırma verisinin toplanmasında;

Ebeveyn/bakımverenler tarafından doldurulan Aile Bilgi Formu, Ebeveyn/ bakımverenlerin yanıtladığı 6-18 Yaş Grubu Çocuk ve Gençler için Davranış Değerlendirme Ölçeği (Child Behavior Checklist For Ages 6-18-CBCL/6-18),

Öğretmenler tarafından yanıtlanan 6-18 Yaş Çocuk ve Gençler İçin Öğretmen Bilgi Formu (Teacher's Report Form/TRF/6-18),

Gençler tarafından yanıtlanan 11-18 Yaş Grubu Gençler İçin Kendini Değerlendirme Ölçeği (Youth Self Report/YSR/11-18) kullanılmıştır.

Her bir ölçekten İçe Yönelim ve Dışa Yönelim davranış belirti puanı elde edilmektedir. İçe Yönelim Problemleri grubunu; Anksiyete/Depresyon, Sosyal İçe Dönüklük ve Somatik Yakınmalar, Dışa Yönelim Problemleri grubunu; Kurallara Karşı Gelme ve Saldırgan Davranışlar alt testleri oluşturmaktadır. Ayrıca her iki gruba girmeyen Sosyal Sorunlar, Düşüce Sorunları ve Dikkat Sorunları alt testleri de ölçekte yer almaktadır. Tüm bu alt testlerin toplamından Toplam Problem puanı elde edilmektedir.

\subsection{Verinin Değerlendirilmesi (Evaluation of Data)}

Veri analizleri "SPSS 10.0" kullanılarak yapılmıştır. CBCL, YSR ve TRF'den elde edilen puanların ailesi yanında kalan, ailesi yanına döndürülen ve yuva-yurtta kalan üç gruba göre farklılık gösterip göstermediğini belirlemek için Krusskal Wallis test kullanılmıştır. Gruplar arasında anlamlı bir fark çıktığında ise, farkın hangi gruptan kaynaklandığını belirlemek için Mann Whitney U-Testi kullanılmıştır. 


\section{BULGULAR (FINDINGS) \\ 5.1. Aile Bilgi Formundan Elde Edilen Bulgular (Findings of the Family Report Form)}

Araştırmaya ailesi yanında kalan 81(\%44.3), aile yanına döndürülen 37 (\%20.2) ve yuva-yurtta kalan 65 (\%35.5) olmak üzere toplam 183 (\%100) çocuk ve genç katılmıştır. Bu çocuk ve gençlerin \%61.2'si erkek, 38.8'i

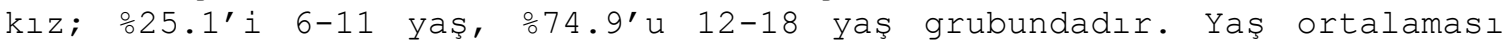
13.3'dür. Çocuk ve gençlerin o14.8'inin sağlık problemi varken, o85.2'sinin sağlık problemi yoktur. Çocuk ve gençlerin bakım modeline göre, yaş, cinsiyet ve sağlık problemi olma durumları arasında anlamlı farklılık saptanmamıştır ( $p>0.05)$.

Aile yanına döndürülen çocukların $\% 67.6^{\prime}$ sının annesi okuma-yazma bilmezken, 32.4'ü okur-yazardır. Ailesi yanında kalan çocukların ○18.5'inin annesi okuma-yazma bilmemekte, ⒏7'si okuryazar, 71.6'sl ilkokul ve o1.2'si lise mezunudur.

Aile yanına döndürülen çocukların \%10.8'inin babası okuma-yazma bilmezken, o89.2'si okur-yazardır. Ailesi yanında kalan çocukların \%11.1'nin babası okur-yazar, \%80.2'si ilkokul, ⒊8'i ortaokul ve \%4.9'u lise mezunudur.

Aile yanına döndürülen çocukların \%8.2'si 13-36 aylarda, \%43.2'si 3-6 yaşlarda ve o48.6'sı 6 ve daha yukarı yaşlarda kurum bakımına alınmışlardır. Yuva-yurtta kalan çocukların \%3.1'i 13-36 aylarda, \%24.6'sı 3-6 yaşlarda ve o72.3'ü 6 ve daha yukarı yaşlarda kurum bakımına alınmışlardır.

Aile yanına döndürülen çocukların o81.1'i aile birliğinin bozulması, ⒑8'i yoksulluk, ⒌4'ü istismar ve \%2.7'sinin diğer nedenlerden dolayı kuruluş bakımına alınmıştır. Yuva-yurtta kalan çocukların 58.5'i aile birliğinin bozulması, ⒙5'i yoksulluk, ⒐2'si istismar, \%9.2'si' diğer nedenler ve \%4.6'sı ihmal nedeniyle kuruluş bakımına alınmıştır.

Ebeveynler, çocuk yuvada iken çocuğun kendileri ile ilişkilerini 7'u iyi, ⒏1'i çok iyi, ⒙9'u ise soğuk olarak bildirmişlerdir. Çocuğun yuvada iken kardeş ilişkilerini ise, ebeveyn ilişkilerine benzer şekilde 7'ünü iyi, \%18.9'unu soğuk (⒏1'inin kardeşi yok) olarak belirtmiş ve ebeveynlerin hepsi çocuk yuva/yurtta iken en az yılda bir kez ziyaret ettiklerini bildirmişlerdir.

\subsection{Aile Yanına Dönüş Sürecine İlişkin Bulgular} (Turning Back to Family Process Findings)

Aile yanına döndürülen çocuk ve gençlerin o62.0'si biyolojik ebeveyni yanına, 28.0'si de akraba yanına döndürülmüştür.

Aile yanına döndürülen çocuk ve gençlerin ebeveynlerinin 32.4'ü çocuk eve döndükten iki-üç ay sonra normal davranmayı öğrendiğini, ○24.3'ü çocuğun davranışında herhangi bir değişikliğin olmadığını, ○18.9'u çocuğun daha mutlu olduğunu, o13.5'inin çocuğun daha sıcak iletişim kurduğunu, \%5.4'ünün çocuğun derslerinin düzeldiğini ve o5.4'ünün de çocuğun yeni ortama uyum sağlayamadığını ifade ettiği görülmüştür.

Aile yanına döndürülen çocuk ve gençlerin ebeveynlerinin \%64.9'u çocuk döndükten sonra sorun yaşamadıklarını, 35'i ise çocuk eve döndükten sonra ailede sorun yaşadıklarını belirtmişlerdir.

Çocuk eve döndükten sonra sorun yaşandığını belirten ebeveynlerin o16.2'si eşleri, o13.5'i çocuklar ve \%5.4'ü ise anne-babaları ile sorun yaşadıklarını belirtmişlerdir.

Aileler yaşadıkları sorunlara çözüm bulma ile ilgili olarak; ○51.3'ü çözüm bulamadığını, idare ettiğini, o13.5'i ise iletişim kurarak çözüm bulmaya çalıştığını belirtmiştir. 


\subsection{Sorun Davranışların Bakım Modellerine Göre Karşılaştırılması (Comparing Problem Behaviors According to Care Models) \\ 5.3.1. Anne Baba ve Bakım Verenlerden Elde Edilen Bulgular (Findings obtained from Parents and Caregivers)}

Tablo 1'de CBCL'den elde edilen puanların çocuk bakım modellerine göre ortalamaları ve standart sapmaları gösterilmiştir. Bakım modellerine göre puan ortalamaları karşılaştırıldığında; Toplam Problem puan ortalamasının aile yanına döndürülen çocuklarda (X=44.8) ailesi yanında $(X=31.7)$ ve yuva yurtta $(X=28,5)$ büyüyen çocuklara göre anlamlı olarak daha yüksek olduğu saptanmıştır $(P<0.05)$.

Sorunların türüne bakıldığında, Dışa Yönelim sorunlarından Kurallara Karşı Gelme, Saldırgan Davranışlar alt test puan ortalamaları ile Dikkat Sorunları alt test puan ortalamaları aile yanına döndürülen çocuklarda diğer iki gruptan daha yüksek bulunmuştur. Dikkat Sorunları alt testi ile İçe Yönelim sorunlarından Anksiyete/Depresyon, sosyal İçe Dönüklük, Somatik Yakınmalar alt test puan ortalamaları yuva yurtta büyüyen çocuklarda diğer iki gruptan daha düşük bulunmuştur $(\mathrm{P}<0.05)$.

Tablo 1. CBCL/6-18 Yaşları arasındaki çocukların sorun davranışlarının gruplara göre ortalama ve standart sapmaları

(Tablo 1. CBCL/6-18 Years old children's behavioral problems according to groups mean and standart deviation)

\begin{tabular}{|c|c|c|c|c|}
\hline Gorun & $\begin{array}{c}\text { Aile Yanına } \\
\text { Döndürülen } \\
\text { N= } 37\end{array}$ & $\begin{array}{c}\text { Ailesi } \\
\text { Yanında } \\
\text { Kalan } \\
\mathrm{N}=81\end{array}$ & $\begin{array}{c}\text { Yuva-Yurt } \\
N=65\end{array}$ & $\begin{array}{c}\text { Kruskal Wallis } \\
\text { Testi }\end{array}$ \\
\hline Davranışlar & $X \pm S S$ & $\mathrm{X} \pm \mathrm{SS}$ & $\mathrm{X} \pm \mathrm{SS}$ & $\mathrm{X}^{2} ; \mathrm{sd} ; \mathrm{p}$ \\
\hline $\begin{array}{l}\text { Anksiyete } \\
\text { /Depresyon }\end{array}$ & $4.9 \pm 2.5$ & $5.6 \pm 3.5$ & $3.4 \pm 3.1$ & $13.448 ; 2 ; 0.001$ \\
\hline $\begin{array}{l}\text { Sosyal İçe } \\
\text { Dönüklük }\end{array}$ & $3.4 \pm 2.9$ & $4.8 \pm 3.3$ & $2.7 \pm 2.7$ & $14.618 ; 2 ; 0.001$ \\
\hline $\begin{array}{l}\text { Somatik } \\
\text { Yakınmalar }\end{array}$ & $3.2 \pm 3.2$ & $1.7 \pm 2.4$ & $.79 \pm 1.5$ & $22.117 ; 2 ; 0.000$ \\
\hline $\begin{array}{l}\text { Sosyal } \\
\text { Sorunlar }\end{array}$ & $4.4 \pm 2.8$ & $3.2 \pm 3.1$ & $4.2 \pm 3.8$ & $4.704 ; 2 ; 0.95$ \\
\hline $\begin{array}{l}\text { Düşünce } \\
\text { Sorunları }\end{array}$ & $5.2 \pm 3.2$ & $2.1 \pm 3.4$ & $2.9 \pm 3.0$ & $29.906 ; 2 ; 0.000$ \\
\hline $\begin{array}{l}\text { Dikkat } \\
\text { Sorunları }\end{array}$ & $5.2 \pm 3.1$ & $4.0 \pm 3.1$ & $2.6 \pm 2.7$ & $20.305 ; 2 ; 0.000$ \\
\hline $\begin{array}{l}\text { Kurallara } \\
\text { Karşı Gelme }\end{array}$ & $5.8 \pm 3.1$ & $2.3 \pm 2.5$ & $4.1 \pm 4.3$ & $24.352 ; 2 ; 0.000$ \\
\hline $\begin{array}{l}\text { Saldırgan } \\
\text { Davranışlar }\end{array}$ & $7.0 \pm 4.4$ & $5.1 \pm 5.7$ & $4.6 \pm 5.1$ & $10.473 ; 2 ; 0.005$ \\
\hline İçe Yönelim & $11.6 \pm 6.6$ & $12.2 \pm 7.9$ & $7.0 \pm 6.5$ & $18.087 ; 2 ; 0.000$ \\
\hline Dışa Yönelim & $12.9 \pm 7.1$ & $7.5 \pm 7.7$ & $8.8 \pm 9.6$ & $15.079 ; 2 ; 0.001$ \\
\hline $\begin{array}{l}\text { Toplam } \\
\text { Problem }\end{array}$ & $44.8 \pm 21.7$ & $31.7 \pm 23.1$ & $28.5 \pm 25.4$ & $13.948 ; 2 ; 0.01$ \\
\hline
\end{tabular}

\subsection{2. Öğretmenlerden Elde Edilen Bulgular (Findings obtained from Teachers)}

Tablo 2'de TRF'den elde edilen puanların çocuk bakım modellerine göre ortalamaları ve standart sapmaları gösterilmiştir. Bakım modellerine göre puan ortalamaları karşılaştırıldığında; Toplam Problem 
puan ortalamalarında bakım modellerine göre anlamlı bir değişim saptanmamıştır $(p>0.05)$.

İçe Yönelim Problemleri alt testlerinden Somatik Yakınmalar ile

Dışa Yönelim Problemlerinden Saldırgan Davranışlar alt test puan ortalamaları aile yanına döndürülen çocuklarda diğer iki gruba göre daha yüksek bulunmuştur $(P<0.05)$.

Benzer şekilde Düşünce Sorunları alt test puan ortalamaları aile yanına döndürülen çocuklarda diğer iki gruba göre daha yüksek bulunmuştur $(P<0.05)$.

Tablo 2. TRF/6-18 Yaşları arasındaki çocukların sorun davranışlarının gruplara göre ortalama ve standart sapmaları

(Tablo 2. TRF/6-18 Years old children's behavioral problems according to groups mean and standart deviation)

\begin{tabular}{|c|c|c|c|c|}
\hline Sorun & $\begin{array}{c}\text { Aile } \\
\text { Yanına } \\
\text { Döndürülen } \\
\text { N= } 28\end{array}$ & $\begin{array}{c}\text { Ailesi } \\
\text { Yanlnda } \\
\text { Kalan } \\
\mathrm{N}=67\end{array}$ & $\begin{array}{c}\text { Yuva-Yurt } \\
N=61\end{array}$ & $\begin{array}{c}\text { Kruskal } \\
\text { Wallis Testi }\end{array}$ \\
\hline Dav & $X \pm S S$ & $\mathrm{X} \pm \mathrm{SS}$ & $\mathrm{X} \pm \mathrm{SS}$ & $\mathrm{x}^{2} ; \mathrm{sd} ; \mathrm{p}$ \\
\hline $\begin{array}{l}\text { Anksiyete } \\
\text { /Depresyon }\end{array}$ & $6.1 \pm 3.5$ & $5.8 \pm 4.3$ & $4.6 \pm 3.3$ & $3.986 ; 2 ; 0.136$ \\
\hline $\begin{array}{l}\text { Sosyal İçe } \\
\text { Dönüklük }\end{array}$ & $2.7 \pm 2.4$ & $3.8 \pm 3.2$ & $3.1 \pm 2.5$ & $3.213 ; 2 ; 0.201$ \\
\hline $\begin{array}{l}\text { Somatik } \\
\text { Yakınmalar }\end{array}$ & $3.4 \pm 3.0 *$ & $1.1 \pm 1.8$ & $.78 \pm 1.1$ & $22.903 ; 2 ; 0.000$ \\
\hline Sosyal Sorunlar & $4.3 \pm 3.1$ & $2.6 \pm 2.6$ & $4.2 \pm 3.4^{\star}$ & $10.854 ; 2 ; 0.004$ \\
\hline Düşünce Sorunları & $5.6 \pm 1.8 * \star$ & $1.8 \pm 2.3$ & $3.1 \pm 2.5 *$ & $40.916 ; 2 ; 0.000$ \\
\hline Dikkat Sorunları & $9.4 \pm 4.8$ & $13.7 \pm 10.0$ & $12.3 \pm 16.1$ & $3.783 ; 2 ; 0.151$ \\
\hline $\begin{array}{l}\text { Kurallara Karşı } \\
\text { Gelme }\end{array}$ & $3.1 \pm 1.6$ & $3.3 \pm 3.7$ & $3.6 \pm 2.9$ & $1.792 ; 2 ; 0.408$ \\
\hline $\begin{array}{l}\text { Saldırgan } \\
\text { Davranışlar }\end{array}$ & $8.6 \pm 2.3 *$ & $7.0 \pm 6.7$ & $7.3 \pm 5.7$ & $7.081 ; 2 ; 0.029$ \\
\hline İçe Yönelim & $12.2 \pm 8.1$ & $10.8 \pm 8.1$ & $8.5 \pm 6.1$ & $4.648 ; 2 ; 0.098$ \\
\hline Dışa Yönelim & $11.6 \pm 3.6$ & $10.4 \pm 9.7$ & $11.0 \pm 7.9$ & $4.945 ; 2 ; 0.084$ \\
\hline Toplam Problem & $45 \cdot 3 \pm 21.3$ & $41.7 \pm 26.8$ & $40.3 \pm 27.6$ & $1.49 ; 2 ; 0.035$ \\
\hline
\end{tabular}

- P<0.05 (3 grup arasında farklılık olup olmadığını belirlemek için Kruskal Wallis testi yapılmıştır. Fark saptandığında farkın hangi gruptan kaynaklandığını belirlemek için ikili gruplar halinde Mann-Withney-U testi yapılmıştır).

\subsubsection{Gençlerden Elde Edilen Bulgular (Findings obtained from Youths)}

Tablo 3'de YSR'den elde edilen puanların çocuk bakım modellerine göre ortalamaları ve standart sapmaları gösterilmiştir. Bakım modellerine göre puan ortalamaları karşılaştırıldığında; Toplam Problem puan ortalamasının aile yanına döndürülen çocuklarda (X=83.8) ailesi yanında $(X=57.0)$ ve yuva yurtta (X=79.1) büyüyen çocuklara göre anlamlı olarak daha yüksek olduğu saptanmıştır $(P<0.05)$. Diğer bir deyişle aile yanına döndürülen çocuklarda daha fazla sorun davranış saptanmıştır.

Sorunların türüne bakıldığında, ailesi yanında yaşayan çocukların Toplam Problem, İçe Yönelim (Somatik Yakınmalar) Dışa Yönelim (Kurallara Karşı Gelme, Saldırgan Davranışlar) ile Düşünce Sorunları ve Sosyal Sorunlar alt testleri puan ortalamaları aile yanına döndürülen ve yuva yurtta büyüyen çocuklardan daha düşük bulunmuştur $(P<0.05)$. 
Aile yanına döndürülen çocukların Dışa Yönelim (Saldırgan Davranışlar) ile Anksiyete/Depresyon alt test puan ortalamaları yuva yurtta büyüyen çocuklardan daha yüksek olduğu bulunmuştur $(\mathrm{P}<0.05)$.

Yuva yurtta büyüyen çocukların Dikkat Sorunları alt test puan ortalamaları diğer iki gruba göre daha yüksek olduğu saptanmıştır $(\mathrm{P}<0.05)$.

Tablo 3. YSR/ 11-18 Yaşları arasındaki gençlerin sorun davranışlarının gruplara göre ortalama ve standart sapmaları

(Tablo 3. YSR/ 11-18 Years old adolescents's behavioral problems according to groups mean and standart deviation)

\begin{tabular}{|c|c|c|c|c|}
\hline Sorun & $\begin{array}{c}\text { Aile Yanına } \\
\text { Döndürülen } \\
\text { N=29 }\end{array}$ & $\begin{array}{c}\text { Ailesi } \\
\text { Yanında } \\
\text { Kalan } \\
\mathrm{N}=58\end{array}$ & $\begin{array}{c}\text { Yuva-Yurt } \\
\mathrm{N}=57\end{array}$ & $\begin{array}{c}\text { Kruskal Wallis } \\
\text { Testi }\end{array}$ \\
\hline Davranışlar & $X \pm S S$ & $X \pm S S$ & $\mathrm{X} \pm \mathrm{SS}$ & $\mathrm{x}^{2} ; \mathrm{sd} ; \mathrm{p}$ \\
\hline $\begin{array}{l}\text { Anksiyete } \\
\text { /Depresyon }\end{array}$ & $11.6 \pm 4.0 *$ & $6.7 \pm 4.6$ & $9.3 \pm 4.9$ & $21.171 ; 2 ; 0.000$ \\
\hline $\begin{array}{l}\text { Sosyal 产çe } \\
\text { Dönüklük }\end{array}$ & $4.4 \pm 2.3$ & $5.5 \pm 2.9$ & $4.5 \pm 3.5$ & $5.497 ; 2 ; 0.064$ \\
\hline $\begin{array}{l}\text { Somatik } \\
\text { Yakınmalar }\end{array}$ & $5.8 \pm 3.5 \star$ & $2.8 \pm 2.9$ & $4.8 \pm 4.5 *$ & $15.435 ; 2 ; 0.000$ \\
\hline $\begin{array}{l}\text { Sosyal } \\
\text { Sorunlar }\end{array}$ & $6.1 \pm 3.1 *$ & $4.1 \pm 3.6$ & $7.2 \pm 4.7 \star$ & $17.509 ; 2 ; 0.000$ \\
\hline $\begin{array}{l}\text { Düşünce } \\
\text { Sorunları }\end{array}$ & $7.0 \pm 2.3 *$ & $4.0 \pm 3.8$ & $7.8 \pm 5.3 *$ & $31.044 ; 2 ; 0.000$ \\
\hline $\begin{array}{l}\text { Dikkat } \\
\text { Sorunları }\end{array}$ & $4.6 \pm 2.9$ & $4.4 \pm 3.4$ & $6.3 \pm 3.4 *$ & $9.445 ; 2 ; 0.009$ \\
\hline $\begin{array}{l}\text { Kurallara } \\
\text { Karşı Gelme }\end{array}$ & $12.5 \pm 2.4^{\star}$ & $3.2 \pm 4.7$ & $9.9 \pm 6.5-9.0 *$ & $62.266 ; 2 ; 0.000$ \\
\hline $\begin{array}{l}\text { Saldırgan } \\
\text { Davranışlar }\end{array}$ & $12.8 \pm 3.7 * \star$ & $5.2 \pm 4.8$ & $8.8 \pm 5.9 *$ & $45.471 ; 2 ; 0.000$ \\
\hline İçe Yönelim & $22.0 \pm 8.5 *$ & $15.1 \pm 9.4$ & $18.8 \pm 11.6 *$ & $10.184 ; 2 ; 0.006$ \\
\hline Dışa Yönelim & $25.4 \pm 5.2 *$ & $8.5 \pm 8.9$ & $18.8 \pm 11.9 *$ & $57.839 ; 2 ; 0.000$ \\
\hline $\begin{array}{l}\text { Toplam } \\
\text { Problem }\end{array}$ & $83.1 \pm 23.9 *$ & $57.0 \pm 29.9$ & $79.1 \pm 42.3 *$ & $17.313 ; 2 ; 0.000$ \\
\hline
\end{tabular}

- P<0.05 (3 grup arasında farklılık olup olmadığını belirlemek için Kruskal Wallis testi yapılmıştır. Fark saptandığında farkın hangi gruptan kaynaklandığını belirlemek için ikili gruplar halinde Mann-Withney-U testi yapılmıştır).

\subsubsection{Aile Yanına Döndürülen Çocukların Sorun Davranışlarına Etki Eden Faktörler (Factors Affecting Children's who were Turn Back to their Family Behavior Problems)}

Aile yanına döndürülen çocukların sorun davranışlarına etki eden faktörler incelendiğinde, cinsiyetin sorun davranışlara anlamlı bir etkide bulunmadığı saptanmıştır ( $>0.05)$.

Çocukların yaşları ile Sosyal İçe Dönüklük alt test puan ortalamasında (rho= 0.161; 0.030) anlamlı pozitif bir ilişki olduğu bulunmuştur $(\mathrm{P}<0.05)$.

Çocukların koruma altına alınma yaşı ile Toplam Problem ve Dışa Yönelim puan ortalamaları arasında anlamlı negatif bir ilişki olduğunu saptanmıştır $(P<0.05)$.

Anne-baba öğrenim düzeyi düşük olan ebeveynlerin Dışa Yönelim problemlerini daha fazla belirttikleri, eğitim düzeyi arttıkça İçe Yönelim problemlerinin daha fazla fark edildiği saptanmıştır. 
Anne-baba, kardeş ilişkisi iyi olan çocuklar ile okulda başarılı olan çocukların sorun davranışlarının daha düşük olduğu saptanmıştır $(\mathrm{p}<0.05)$.

\section{TARTIŞMA (DISCUSSION)}

Çalışmamızda CBCL ve YSR'den elde edilen Toplam Problem puan ortalamaları aile yanında döndürülen çocuklarda diğer iki gruba göre daha yüksek bulunmuştur. Bakım modellerine göre TRF'den elde edilen Toplam Problem puan ortalamaları arasında ise anlamlı farklılık saptanmamıştır.

Çocukların, aileden ayrı yaşamalarının uzun dönem etkileri ile ilgili yapılan çalışmalar, çocuk biyolojik aile yanına döndürülse veya evlat edinilse bile anti sosyal davranışlar gösterdiği yönündedir [16, 18 ve 19].

Davranış problemleri, yoksulluk ve işsizlik ile bağlantılı kötü ev koşulları ve sosyal çevreye sahip şehrin kenar mahallelerinde daha sıklıkla görülmektedir [36]. Yapılan bu araştırmada, aile yanına döndürülen, ailesi yanında ve kuruluşta büyüyen çocukların sosyoekonomik koşulları oldukça benzerdir. Zocolilı ve arkadaşları çocukluğunu kurumda geçirenlerin, kendileri ile aynı sosyo-ekonomik sorunlara sahip çevrede aile yanında yetişen çocuklara göre yetişkinlikte daha fazla ve yaygın sosyal işlev bozukluğu gösterdiklerini belirtmişlerdir [38].

Korunma altındaki çocuklarla ilgili İngiltere ve Amerika'da yürütülen ve eve dönen çocukları da içeren çalışmalarda, eve dönen çocukların bakım altında olan çocuklara göre daha ciddi duygusal ve davranış problemler gösterdikleri, eğitime katılım ve uyumun daha düşük, suça sürüklenme oranlarının daha yüksek olduğu anlaşılmıştır [22].

Araştırmada kullanılan ölçme araçları ile aynı ölçme araçlarının uygulandığı, tabakalı, çok aşamalı, kümeli, olasılık örneklemesi yöntemiyle yapılan, 4488 çocuk hakkında anneden, 2340 öğretmenden ve 2206 gençten bilgi toplanan Türkiye Ruh Sağlığı Profili Araştırması (1998) verilerine bakıldığında; ebeveynlerin ve gençlerin bildirdiği Toplam Problem puan ortalamalarının aile yanına döndürülen, ailesi yanında kalan ve yuva-yurtta bakılan çocuklardan daha düşük olduğu saptanmıştır $[9,10$ ve 11$]$.

Akman ve Balat tarafından 1998-1999 yıllarında Ankara'da yapılan çalışmada ailesi yanında kalan gençler (YSR), Toplam Problem (X= 45.3) puan ortalamalarını daha düşük bildirmişlerdir [1].

Üstüner ve arkadaşları tarafından 2004 yılında Ankara'da koruyucu ailelerle yapılan çalışmada, koruyucu aile yanında bakılan çocukların Ebeveynlerin bildirdiği Toplam Problem ( $\mathrm{X}=31.8$ ) puan ortalamalarının aile yanına döndürülen çocuklardan daha az olduğu, ailesi yanında kalan $(X=31.7)$ çocuklarla benzer olduğu görülmektedir [32] .

Aileye dönen çocukların, koruyucu ailede bakılan ve evlat edinilen çocuklarla karşılaştırıldığında, daha az ilgi gördüğü, benzer zorluklarla başa çıkmada da biyolojik ebeveynlerinden daha az destek gördükleri anlaşılmaktadır. Meltzer (2003) yaptığı çalışmada biyolojik ebeveynleri ile yaşayan çocukların koruyucu aile yanında yaşayan çocuklara oranla en az iki kat daha fazla anksiyete bozukluğu (\%20'ye \%8) dört kat fazla depresyon yaşadığını (\%9'a \%2) bulmuştur [24] .

Aile yanına döndürülen çocukların \%91.9'unun en az bir kuruluş değiştirdiği, yuva yurtta büyüyen çocukların ise o43.1'inin hiç kuruluş değişikliği yaşamadığı, 33.9'unun sadece bir kuruluş değiştirdiği bulunmuştur.

Bowlby, çocuğun bilinçaltında sosyal ilişkiler için model oluşturduğunu belirtir. Çocuğun erken dönemdeki gördüğü sevgi ve güven kendisini sevilmeye değer ve güvenilir olarak görmesini sağlar. Bu da sağlıklı bir bağlanma ile gerçekleşebilir. Ancak çocuğun bağlanma 
gereksinimi karşılanmaz ise kendisiyle ilgili imgesi de zayıf olacak ve istenmeyen bir çocuk sadece anne babası tarafından değil, hiç kimse tarafından istenmediğine inanacaktır. Çalışmamızda aile yanına döndürülen çocukların kuruluşta kaldıkları süre içinde birçok kez yer değişikliği yaşadıkları ve bağlanma ihtiyaçlarının yeterince karşılanmadığını düşündürmektedir [4] .

$$
\text { Anne baba ilişkilerine göre puan ortalamaları }
$$

karşılaştırıldığında; Toplam Problem puan ortalamasının anne baba ilişkisi kötü $(X=40.9)$ ve orta $(X=34.6)$ olan çocukların iyi (X= 20.9) olanlara göre daha yüksek olduğu saptanmıştır $(P<0.05)$. Sorunların türüne bakıldığında, anne baba ilişkisi kötü ve orta olanlarda İçe Yönelim (Anksiyete/Depresyon, Sosyal İçe Dönüklük, Somatik Yakınmalar), Dışa Yönelim (Saldırgan Davranışlar), Sosyal Sorunlar, Dikkat Sorunları alt testleri puan ortalamaları anne baba ilişkisi iyi olanlara göre yüksek bulunmuştur $(P<0.05)$.

Verilerin toplanması sırasında, aile yanına döndürülen çocukların 24.3'nün ebeveynleri, çocuğu almak istemediklerini, kuruluş tarafından kurumda sorun yaratması, okul devamsızlığının olması ve kuruluşta kalması halinde çocuğun daha çok zarar göreceği bildirilerek çocuğun kendilerine verildiğini ve bu nedenle sıkıntı yaşadıklarını ifade etmişlerdir. ⒑8 çocuğun ebeveyni ise, maddi yetersizlik nedeniyle çocuklarını aldıklarını, ⒉8'de üvey anne istememesine rağmen biyolojik babanın eşine "Boşanırım" diyerek ikna etmesi üzerine çocuğunu aldığını ifade etmiştir. 40.5 çocuğun ailesi çok isteyerek aldığını belirtmiş, o21.6'sının ailesi ise net bir ifadede bulunmamışlardır. Bazı aileler ise, çocuklarının koruma kararı kalkıp sadece nakdi yardımla desteklediği zaman, büyüdüklerinde 3413 sayılı yasadan yararlanamayacakları için koruma kararlarının kaldırılmasını hiç istemediklerini belirtmişlerdir

Genel olarak tüm ebeveynlerin çocukları için genel kaygısının, iş bulma konusu olduğu gözlenmiştir. Aile yanına döndürülen çocukların ve ebeveynlerinin, eve dönüş sürecine hazırlanmadan döndürülmeleri ve çocukların yuva-yurttan ayrılma ile ilgili düşüncelerinin sorulmaması, fikirlerinin dikkate alınmaması veya çocuğun aileye çok isteyerek dönmemesi, o40.5'nin kardeşlerinin ailesi yanındayken, kendilerinin yuvaya bırakılması ve o18.9'unun da yuva-yurtta iken yılda bir kez ziyaret edilmesi dolayısıyla ebeveynleri ile yakın ilişki sağlanamadığı, aile yanına döndürülen çocukların yuva-yurt grubuna göre daha fazla kuruluş değişikliği yaşamaları nedeniyle sorun davranışlarının yuva-yurt grubuna göre daha fazla olduğu değerlendirilmektedir. Ayrıca yuva-yurtta bakılan çocukların ihtiyaçları görevliler tarafından karşılanmakta olduğundan çocuğun çok fazla sorumluluğu olmamaktadır. Fakat evde evin sorumluluğuna ve kurallarına katılım gerektiğinden çocuğun evin sorumluluğu ve kurallarına uyumunda sorun yaşanmasından dolayı bu durumun ebeveynlerle çatışma yaşanmasına neden olabildiği düşünülmektedir.

Aile yanına döndürülen çocuklardan dördü (\%10.8) tekrar kuruluş bakımına geri dönmüştür. Bu çocukların geri dönme nedenlerine bakıldığında üçünün geri döndüğü ebeveyninin eşinden ayrıldığı ve çocuğun sorumluluğunu yerine getiremeyeceğini belirttiği, birinin de vefat ettiği görülmüştür. Bu çocuklarla yapılan görüşmelerde kurum bakımına yeniden dönüşün çocukları üzdüğü anlaşılmıştır. Fakat geri döndüğü ailesi parçalanan iki çocuğun, bu süreçte ve sonrasında çok fazla problem yaşadığı bu nedenle kuruluşa dönmeyi çok istedikleri ve kuruluşu kurtuluş olarak gördükleri öğrenilmiştir.

Bakım verenler, yuva-yurtta büyüyen çocuklarda, İçe Yönelim problemlerini diğer iki gruba göre daha az bildirmişlerdir. Yurt içi ve yurt dışında yapılan çalışmalarda da araştırma bulgularına benzer şekilde, kuruluş bakımında büyüyen çocuklarda dışa yönelim sorunlarının 
içe yönelim sorunlarına göre daha fazla görüldüğü bildirilmiştir. Bu durumun nedeni olarak, çocuğun küçük yaşta ailesinden ayrılmasının bağlanma sorunlarına neden olması ve bağlanma sorunlarının da dışa yönelim sorunlarını arttırdığı yönündedir. Benzer şekilde Erol ve Şimşek, Şimşek ve arkadaşları tarafından yapılan araştırmalarda, anneler/bakım verenler içe yönelim sorunlarını kuruluş bakımında büyüyen çocuklarda ailesi yanında büyüyenlere göre daha az, dışa yönelim ve toplam problemi sırasıyla 3.7 ve 2.3 kat oranında anlamlı olarak yüksek bildirmişlerdir [12 ve 26].

İçe Yönelim problemleri yaşayan çocuğun, bu durumundan sadece kendisinin etkilenmesi ve çevreye zararının dokunmamasından dolayı dikkat çekici olmaması nedeniyle göz ardı edilebilmektedir. Dışa Yönelim problemleri ise çocuğun sadece kendisi ile değil, olumsuz davranışlarının diğer kişileri de etkilemesi ve kuruluş bakımının kalabalık ortam olması nedeniyle bu davranışların dikkati çekmesi ve kısa zamanda önlem alınmaya ihtiyaç duyulması nedeniyle daha fazla fark edilmektedir. Bu durum, İçe Yönelim problemlerinin fark edilmesi konusunda yuva-yurtta personelinin eğitim ihtiyaçlarının olduğunu göstermektedir.

Bakım ortamının kaliteli olmasının da etkisi olabileceği düşünülmektedir. Elizabeth Fernandez'in yürüttüğü bir çalışmada küçük de olsa çocuğun koruma altına alındıktan sonraki gelişmesini sağlayan bakım sisteminin çocuğa bakım verenlerin mesleki başarıları ile bağlantılı olduğu sonucuna varmıştır [15]. Şimşek ve arkadaşları, Erol ve Şimşek tarafından yapılan araştırmada da bakım verenin destekleyici yaklaşımı ve yeterlik düzeyinin yüksekliğinin sorun davranış puanını azaltan faktörler olduğu saptanmıştır [26 ve 12]. Kütahya Çocuk Yuvasının il merkezinde ve iyi bir semtte ve apartmanların arasında oluşu, gönüllü desteğinin iyi bir şekilde sağlanması, çocuk sayısının az olması, çalışan personelin çocuklara olan yakın ilgisinin (kış mevsiminde grup sorumlularının tıpkı bir anne gibi çocuklara panço, atkı, bere örmeleri, dersleri ile bire-bir ilgilenmeleri, birlikte pazara gitmeleri ve çocukların ihtiyaçlarını alış veriş merkezlerinden kendilerinin almalarının sağlanması, sosyal ve kültürel faaliyetlerinin yoğun olması,... vs) sorun davranışları azalttığı düşünülmektedir.

Sosyal Hizmetler Çocuk Esirgeme Kurumu tarafından 2005 yılında "Çocuk Koruma Sisteminin Değerlendirilmesi" başlığı altında yapılan araştırma sonuçlarına göre Sosyal ve Ekonomik Destek ile kuruluş bakımından aile yanına döndürülen çocukların 을 $28,9^{\prime} \mathrm{u}$ kız ve \% $70,8^{\prime} \mathrm{si}$ erkek olduğu ve 13-15 yaş diliminin daha yukarı yaş dilimleriyle karşılaştırıldığında göreli bir ağırlığı bildirilmiştir. Yapılan bu araştırmada da aile yanına döndürülen çocukların ebeveynlerinin erkek çocuklarını geri alma eğilimlerinin olduğu ve 13-15 yaş grubunda olan çocuklarını daha fazla tercih ettikleri görülmektedir [39].

11-18 yaş Gençler İçin Kendini Değerlendirme Ölçeğinin (YSR) kullandığı araştırmalarda sorun davranışların yaşla birlikte arttığı bulunmuştur [1 ve 6].

Kardeş ilişkisine göre puan ortalamaları karşılaştırıldığında; Toplam Problem puan ortalamasının kardeş ilişkisi kötü olan çocukların $(X=40.9)$, orta $(X=32.6)$ ve iyi $(X=25.4)$ olanlara göre daha yüksek olduğu saptanmıştır $(P<0.05)$. Sorunların türüne bakıldığında, kardeş ilişkisi kötü olanlarda İçe Yönelim sorunlarından Anksiyete/Depresyon, Sosyal İçe Dönüklük ve Somatik Yakınmalar ile Saldırgan Davranışlar alt test puan ortalamaları kardeş ilişkisi orta ve iyi olanlara göre yüksek bulunmuştur $(P<0.05)$.

Kardeşler arasında iyi ilişkilerin olması, aile içinde meydana gelebilecek olumsuz olaylarda (boşanma, ölüm, işsizlik,... vs) sosyal destek işlevi görmektedir [2]. Yakın bir kardeş ilişkisine sahip olmak, okulda yeterince arkadaş edinememenin olumsuz etkilerini bir ölçüde 
giderebilmekte [8] ve kardeşler, öneri ve rehberlik kaynağı olarak işlev görebilmektedirler [29 ve 30].

Kardeşler arasındaki ilişki, aile bireylerinin insanın hem kendince hem de başkalarınca tanımlanan toplumsal kimliğinin bir parçası olması ve kişilerin daha sonraki yaşamlarında diğer ilişkilerine temel oluşturması açısından önemlidir [2 ve 21]. Kardeş ilişkisinin kalitesi, ergenlerin sadece akran ilişkilerini değil, uyumlarını da etkilemektedir [28].

Arkadaş ilişkisine göre puan ortalamaları karşılaştırıldığında; Toplam Problem puan ortalamasının arkadaş ilişkisi kötü olan çocukların $(X=90.1)$, iyi (X=63.5) olanlara göre daha yüksek, arkadaşı olmayanlara $(\mathrm{X}=103.1)$ göre daha düşük olduğu saptanmıştır $(\mathrm{P}<0.05)$. Sorunların türüne bakıldığında, arkadaş ilişkisi kötü olanların Dışa Yönelim (Saldırgan Davranışlar, Kurallara Karşı Gelme) sorunları ile Sosyal Sorunlar ve Düşünce Sorunları alt test puan ortalamaları arkadaş ilişkisi orta ve iyi olanlara göre yüksek, arkadaşı olmayanlara göre daha düşük olduğu bulunmuştur $(P<0.05)$.

Araştırmaya katılan gençlerin \%69.4'ünün yakın bir arkadaşı varken, 30.6'sının yakın bir arkadaşı olmadığı bulunmuştur. Gençlerin belirttiği yakın bir arkadaşa sahip olma durumlarına göre dağılımları bakım modellerine göre anlamlı farklılık göstermektedir $(p<0.05)$. Aile yanına döndürülen çocukların \%48.3'nün yakın bir arkadaşı varken ailesi yanında kalan çocukların \%96.6'sının, yuva yurtta büyüyen çocukların ise o52.6'sının yakın bir arkadaşının olduğu bulunmuştur. Aile yanına döndürülen ve yuva yurtta büyüyen çocukların yakın bir arkadaşa sahip olma durumlarının benzer ve arkadaş edinmekte güçlüklerinin olduğu, ailesi yanında kalmakta olan çocukların ise daha hemen hemen tümünün yakın bir arkadaşa sahip olduğu saptanmıştır.

Woodward ve Fergusson, dokuz yaş çocukların akran ilişkilerindeki problemlerin derecesini ve 18 yaşından sonra karşılaşacağı başarısızlık ve işsizlik risklerini incelemişlerdir. İlk akran ilişkilerinde problem derecesi yüksek olanların, işsizlik ve başarısızlık riskinin diğerlerinden daha yüksek olduğu görülmüştür [34]. Helsen ve arkadaşları, 12-24 yaş arası ergenlerle yaptıkları çalışmada, aile ve arkadaşların sosyal desteği arasındaki ilişkiyi incelemişlerdir. Araştırmada, arkadaş desteğinin algılanan ailesel desteğin seviyesine bağlı olduğu, yüksek ailesel desteğin, arkadaşsal desteğin olumlu etkisini arttırdığı görülmüştür [17]. İlkokulun ilk dönemlerinde akranları tarafından reddedilen çocukların, adolesan ve yetişkinlik dönemlerinde davranış bozukluğu geliştirme riski daha yüksektir. Reddedilen çocukların; gruba, çeteye eğilimleri fazladır ve grupta çocuklardan her biri diğerinin anti-sosyal davranışını desteklemektedir [3].

Aile yanına döndürülen ve yuva-yurtta büyüyen çocukların anne öğrenim düzeylerinin oldukça düşük olduğu görülmektedir. Çocukların ilk eğitimlerini aldıkları aile ortamlarında ve özellikle anneleri tarafından töre, gelenek ve görenekler doğrultusunda alışılagelmiş yöntemlerle eğitildikleri açıktır. Okuma-yazma bilmeyen anne-babanın, çocuğunu tanımak ve ona rehberlik edebilmek için hiçbir bilimsel aydınlanma olanağı yoktur. Dolayısıyla dışa yönelen davranışlar gözle göründüğü için fark edilmesi kolay; içe yönelen davranışların ise ifade edilmedikten sonra fark edilmesi, kişiyi iyi tanımaya bağlı olduğu için daha zordur. Ayrıca eğitilmiş olmak, anne-babaya hiç değilse kendi davranışlarını eleştirme ve kontrol etme olanağı vermektedir. Yavuzer ve arkadaşları tarafından suçlu çocuklarla yapılan araştırmada (1993) deneklerin annelerinin o76.6'sının, babalarının da o40.7'sinin okumayazma bilmediği saptanmıştır [35].

Yoksul ailede anne-babanın okuma-yazmasının hiç olmaması veya çok zayıf olması nedeniyle çocuklarla sözlü iletişim yetersiz kalır [37]. 
Anne-babanın çocukla sözlü iletişiminin ve çocuğu zihinsel uyarmasının yetersiz oluşu, çocuğun dil gelişiminde geriliklere neden olur. Dil yetenekleri daha iyi okul performansının belirleyicisidir. Dilin yetersizliği, okuldaki başarısızlığın en önemli nedenidir. Zengin sözcük dağarcığı olmayan çocuklarda, kavram oluşturma yetisi zayıflar [33]. Araştırma verilerinin toplanması sırasında 8-12 yaş grubu çocuklardan bazılarının "Cinsiyet" gibi bazı temel kavramların anlamlarını bilmedikleri gözlenmiştir. Matematik problemlerinin anlaşılması da okuma ve okuduğunu anlama becerisi gerektirdiği için ve bu çocukların çoğunluğunda temel dil becerileri kazanılmadığından okuma ve okuduğunu anlama ve matematik becerileri yaşıtlarına göre daha zayıftır.

Aile yanına döndürülen erkek ergenlerin o50'si, gerçekte ailelerinin yanında çok mutlu, huzurlu ve rahat olmadıklarını, aile ve akraba ilişkilerinin birçok olumsuz yönlerini gördüklerini fakat yuvayurtta ki yaşamalarına göre daha özgür olduklarını, toplum tarafından dışlanmaktan kurtulduklarını, kuruma geri dönmeyi istemediklerini bildirmişlerdir. Kız ergenlerin ise, aile ilişkileri konusunda bilgi vermekten kaçındıkları gözlenmiştir. Aile yanına döndürülen 6-11 yaş çocukların ise ailelerinin yanında mutlu oldukları ve ziyaret için bile olsa kuruluşa gelmek istemedikleri öğrenilmiştir.

çocuğun ve ailenin eve dönüş sürecine çok iyi hazırlanması, çocuğun aile yanına döndükten sonra da izlenmesi ve çocuk ve ailenin sağlık, sosyal ve danışmanlık hizmetleri yönünden desteklenmesinin önemi, aile yanına döndürülen çocukların daha fazla sorun davranışa sahip olmaları ve aile yanından tekrar kuruma dönmek zorunda kalan çocuklar yönünden daha iyi anlaşılmaktadır.

\section{SONUÇ VE ÖNERILER (CONCLUSIONS AND RECOMMENDATIONS)}

Ölçeklerden elde edilen bilgilere bakıldığında; ailesi yanına döndürülen çocukların sorun davranışlarının diğer iki gruba göre daha fazla olduğu, anne-baba öğrenim düzeyi, anne-baba ile ilişkiler, kardeş, akran ilişkileri ve okul başarısının sorun davranışlarla ilişkili olduğu, anne-baba öğrenim düzeyinin artması, olumlu anne-baba, kardeş, akran ilişkileri ve okul başarısının çocukların sosyal, duygusal davranış problemleri için koruyucu faktörler olduğu bulunmuştur.

Aile yanına döndürülen çocukların, yuva-yurtta ve ailesi yanında kalan çocuklara göre, yuva-yurtta kalan çocukların da ailesi yanında kalanlara göre daha fazla sorunlu davranışlarının olması nedeniyle, öncelikle çocuğu, kurum bakımına almadan ailesi yanında bakılmasını sağlayacak makro sistem düzeyinde önlemlerin alınmasının gerekli olduğu düşünülmektedir.

Aile yanına döndürülen ve yuva-yurtta kalan çocukların, yuvaya veriliş nedenlerinin büyük oranda boşanma nedeniyle aile birliğinin bozulması olduğu görülmektedir. Makro düzeyde ailenin sağlık, eğitim, ekonomik ve sosyal desteğin sağlanarak aileyi koruyucu çalışmalara ağırlık verilmesi önem taşımaktadır. Ülkenin bir çok ilinde olduğu gibi Kütahya İl'nde de evliliklerin erken yaşta ve çoğunlukla kendini geçindirebilecek maddi imkanlardan yoksun olarak yapılması, gelecekteki evlilik çatışmalarını arttırmakta, son yıllarda sık gündeme gelen kadına yönelik şiddeti beraberinde getirmekte, boşanmalara zemin hazırlamakta ve bunun sonucunda çocuk aile içinde ihmal ve istismar edilebilmektedir. Yeni evlenecek çiftlerin, evlenmek için başvurmaları sonrası bir dizi kan testinden geçme zorunlulukları olduğu gibi, Sağlık, Eğitim, Aile ve Sosyal Politikalar ìl Müdürlükleri ile adliyeden sağlanacak olan bir hukuk görevlisinden oluşan bir ekiple, çocuk gelişimi ve eğitimi, aile planlaması, aile içi ilişkiler, iletişim, çatışma çözme, stresle başa çıkma, insan hakları konularında ve ihtiyaç duyulması halinde eşlerin kendine yeterli hale getirebilecek beceri eğitimi almaları zorunlu hale getirilmelidir. Yeni evlenecek çiftlerin, kendi kişisel özelliklerini 
tanıma, beklentilerini belirleme, aile içi uyumları ve birbirlerinden beklentileri daha gerçekçi olabilecektir. Aile ve sosyal Politikalar Bakanlığı ile Belediyeler Birliği arasında imzalanan protokol ile Aile ve Sosyal Politikalar Bakanlığınca 2012 yılında Evlilik Öncesi Eğitim Programı başlatılmıştır. Fakat belediyelerden yeterli destek sağlanamadığı için eğitimler daha çok Polis Okulları, askeri birliklerde erlere ve Meslek Yüksek Okulu öğrencilerine yönelik yapılmaya devam etmektedir.

Çocuk, koruma altına alınıp kuruluşa yerleştirildiğinde, çocuk ve aile travma yaşamaktadır. Çocuk kuruluş bakımında iken, sadece çocuk ile ilgili rehabilite edici çalışmaların yapılması, aile ile ilgili çalışmaların hiç yapılmaması veya yapılamaması nedeniyle aile çocukla birlikte rehabilite edilememekte, aile kendi haline bırakılmaktadır. Bu durumun aile ile çocuğun gelişim hızının farklı olmasına, aradaki bağların zayıflamasına ve çocuğun aile yanına dönüş sürecinde sorunlar yaşanmasına neden olduğu düşünülmektedir. Bu nedenle kuruluş bakımında olan çocuğun ailesine yönelik çalışmaların yapılmasının, yönetmeliklerle belirlenmesi ve ailelerin bu çalışmalara katılımları zorunlu hale getirilmelidir.

Browne, aile yanına döndürülme sürecinde çocuk ve ailenin dönüş sürecine hazırlanması ve dönüş gerçekleştikten sonra önce ilk 3 ay, daha sonraki iki yıllık dönemde, altı ayda bir aile ve çocuğun izlenmesinin gerekli olduğunu belirtmiştir [5]. Aile yanına döndürülen çocuk ve gençlerin eve dönüş sürecine iyi hazırlanmadıkları, hatta bazı ebeveynlerin belirttiği gibi çocuğun eve geri dönüşünün yuva-yurtta sorun yaşatmasından dolayı zorla kabul ettirildiği bildirilmiştir. Ayrıca döndürülen ve yuva-yurtta sorun yaşadığı belirtilen çocukların, aile yanında hiçbir destek tedavisi almadığı görülmektedir. Sosyal ve ekonomik destek yönetmeliği hükümlerine göre, çocuk aile yanına döndürüldüğünde ilk önce altı aylık dönem için yardım yapıldığından, önce altı ayda, daha sonra bir yılda ve daha sonra iki yılda bir izlenmektedir. Yeni başlayan bir uygulama ile ilk yardımlar bir yıl süreli başlatılacağından izlenme süresi uzayabilecektir. Personel eksikliği nedeniyle izleme sürelerinde aileye yapılacak olan nakdi yardımın devam edip etmeyeceğine yönelik rapor düzenlenmekte, fakat sosyal-duygusal ve tedaviye yönelik ihtiyaçlar belirlenememekte ve sosyal-duygusal destek verilememektedir. Aile yanına çocuk dönmeden önce çocuğun tedavi ihtiyacı belirlenip, aile yanında iken devamının sağlanmasına yönelik tedbirlerin alınması oldukça gereklidir. Bu nedenle çocuğun aile yanında izlenmesi süreci ile ilgili daha detaylı formların oluşturularak, çocuk ve ailenin sağlıklı gelişimi için bir sonraki döneme ilişkin hedeflerin belirlenmesi ve raporlaştırılması, bir sonraki ziyaretlerde hedeflere ulaşılıp ulaşılamadığının kontrol edilmesinin gerekli olduğu değerlendirilmektedir.

Kağıtçıbaşı'nın yaptığı "Çocuğun Değeri" araştırmasında, sosyokültürel düzeyin artması ile çocuğun ekonomik değerinin azaldığı, psikolojik değerin arttığı bulunmuştur [22]. Sosyo-kültürel düzey, eğitimle artmakta olduğundan, anne-babanın eğitim düzeyinin artması, yeterli ebeveynlik becerilerinin artmasını beraberinde getirdiğinden, toplumun eğitim seviyesinin yükseltilmesine yönelik çalışmalara ağırlık verilmesi önemlidir.

Dört yıldan fazla süre yardım alan aileler olduğundan, ailelere sadece ekonomik yardım yapılması, kendilerine yeterli hale gelebilecek çalışmaların olmaması nedeniyle ailenin dört yıl öncesi ve sonrası fark etmemekte, bu aileler yapılan yardıma bağımlı hale gelmektedirler. Verilerin toplanması sırasında bazı annelere iş önerilmiş, fakat "eşim istemiyor" diyerek iş tekliflerini geri çevirmişlerdir. Bu nedenle bu aileler için yönlendirici rehberlik yapılmasının önemli olduğu değerlendirilmektedir. 
Özellikle aile yanına döndürülen ve yuva-yurtta kalan çocuklar olmak üzere ailesi yanında kalan çocuklar da dahil tüm çocukların kavram ve dil gelişimlerinin oldukça geri olduğu, orta çocukluk döneminde, erken destek çalışmalarının önceden yapılmaması nedeniyle dolayı okul başarılarının düşük olduğu değerlendirilmektedir. Düşük okul başarısı da çocuğun sorun yaşamasına neden olmaktadır.

Kuruluşlarda çocukların sorumluluklarının daha az, düzenlenen sosyal ve sportif faaliyet ile gezilerin daha fazla olmasi, fiziksel ihtiyaçlarının daha rahat bir ortamda karşılanması, akranlarla aynı yaşam ortamının paylaşılması nedeniyle özellikle büyük yaş grubu çocukların kuruluş bakımını, evlerine tercih ettikleri gözlenmiştir.

Kuruluş bakımında kalan çocuklarla yapılan görüşmelerde, çocukların 3413 sayılı yasadan yararlanarak iş imkanına sahip olmalarının, çocukları rahatıığa sevk ettiği, başarı ve gelecek beklentisini düşürdüğü ve ailelerinin de iş imkanını çok önemsedikleri gözlenmiştir. Ülkemizde yoksulluk sınırında ve altında yaşayıp, çocuğunun sorumluluğunu alan binlerce aile yaşamaktadır. Tüm çocukların eşit haklardan yararlanma fırsatının sağlanması için 3413 sayılı yasanın yeniden gözden geçirilmesinin uygun olacağı değerlendirilmiştir.

Çocukların kuruluş bakımına alınmaması yönünde, aileyi destekleyici ve koruyucu çalışmaların önemli olduğu, kuruluş bakımı gibi tedavici edici çalışmaların arttırılmasına dönük yeni kuruluşların açılması yerine, aileye ilk elden hizmet götürecek Aile Destek Hizmet Merkezlerinin ilgili yerleşim yerlerinde bulunan Aile Hekimlikleri ve Halk Sağlığı birimleri ile işbirliği halinde hizmetlerinin yaygınlaştırılması ve etkin hale getirilmesinin uygun olacağı değerlendirilmiştir. Ayrıca çocukların okul başarıları için, dil ve kavram gelişimlerinin önemli olmasından dolayı, okul öncesi eğitim ile gerektiğinde ev ziyaretleri şeklinde yapılacak olan anne-bebek, anneçocuk, baba eğitim programlarının geliştirilmesinin uygun olacağı değerlendirilmektedir.

\section{KAYNAKLAR (REFERENCES)}

1. Akman, B. ve Balat, G., (2006). Lise Öğrencilerinin Psikolojik Durumlarının Sosyo-demografik Özelliklerine Göre İncelenmesi. Çocuk ve Gençlik Ruh Sağlığı Dergisi: 13 (1). ss: 3-12

2. Bayhan, P.S. VE Artan, İ., ( 2004). Çocuk Gelişimi ve Eğitimi. İstanbul: Morpa Kültür Yayınları.

3. Bee, H., (1992). The Developing Child. New York: Harper Collins College Publishers.

8. Bowlby, J., (1973). Attachment and Loss. Separation, anxiety and anger. New York: Basic Books.

5. Browne, K., ( Çev. Uzm. Psk. İlkiz Atınoğlu-Dikmeer) (2008). "Çocukların Kurum Bakımından Alınması ve Hizmetlerin Dönüştürülmesine İlişkin Avrupa Birliği Daphne / Dünya Sağlık Örgütü Eğitim ve Bilgilendirme Paketi". Prof. Dr. Mualla ÖzTÜRK XX. Sempozyumu. Ankara: Ankara Üniversitesi Tıp Fakültesi Çocuk / Ergen Ruh Sağlığı ve Hastalıkları Anabilim Dalı Yayınları No:6, Ss:259-264

6. Conners, C.K., Wells, K.C., and Parker-James D.A., (1997). A New Self Report Scale for Assessment of Adolescent Psychopathology: factor, structure, reliability, validity and diagnostic sensivity. Journal of Abnormal Child Psychology, 25, ss:487-498.

7. De-Instituationalising and Transforming Children's Services. A Guide to Good Practice (2007). European Commission Daphne Programme Directorate-General Justice and Home Affairs In Collaboration with Who Regional office for Europe and The University of Birmingham, UK. 
8. East, P. and Rook, K., (1992). Compensatory Patterns of Support Among Children's Peer Relationships: A Test Using School Friends, Non School Friends and Siblings. Developmental Psychology, 28 , ss: 163-172.

9. Erol, N., Arslan, B.L. ve Akçakın, M., (1995). The Adaptation and Standardization of the Child Behavior Checklist Among 6-18 YearOld Turkish Children Eunethydis: European Approaches to Hyperkinetic Disorder. Zurich: Fotoratar. ss:97-113.

10. Erol, N. ve Şimsek, Z., (1998). Çocuk ve Gençlerde Ruh Sağlığı: Yeterlik Alanları, Davranış ve Duygusal Sorunların Dağılımı. Türkiye Ruh Sağlığı Profili Raporu. Ankara: Eksen Tanıtım Ltd. Şti.

11. Erol, N. ve Şimsek, Z., (2000). Mental Health of Turkish Children: Behavioral and Emotional Problems Reported by Parents, Teachers and Adolescents. International Perspectives on Child and Adolescent Mental Health. Elsevier Science Ltd, ss:223-247

12. Erol, N. ve Şimsek, Z., (2000). "Farklı Bakım Modellerinde Çocuk Ruh Sağlığı". Koruyucu Aile, Evlat Edinme Hizmetleri ile Ruh Sağlığı. Ankara: Ankara Üniversitesi Tıp Fakültesi Çocuk / Ergen Ruh Sağlığı ve Hastalıkları Anabilim Dalı Yayınları No:6, ss:169179 .

13. Erol, N., (2004). Yuvalar Sorunun mu Yoksa Çözümün mü Parçası?" R. Uslu (ed.) Koruma Altındaki Çocuklar, Ankara Üniversitesi Çocuk Ruh Sağlığı ve Hastalıkları Anabilim Dalı Yayınları. Yayın no: IX, ss: 33-140.

14. Erol, N., Şimşek, Z. ve Üstüner, S., (2005). Çiçekli Dünyamda Elimi Yalnız Bırakma; Dünyada ve Türkiye'de Çocuk Koruma Sistemleri; Kurum Bakımı, Koruyucu Aile ve Evlat Edinme. Ankara: Ümit Matbaacılık.

15. Fernandez, E., (1996). Significant Harm: Unraveling Child Protection Decisions and Substitute Care Careers of Children. England: Avebury, Aldershot.

16. Goldfarb, W. (1945). Effects of Psychological Deprivation in infancy and subsequent Stimulation. American Journal of Psychiatry. 102, ss:18-33.

17. Helsen, M., Vollebergh, W., and Meeus, W., (2000). Social Support from Parents and Friends and Emotional Problems in Adolescence. Journal of Youth and Adolescence, 29 (3), ss:319-335.

18. Hodges, J. and Tizard, B., (1989a). Social and Family Relationships of Ex-institutional Adolescents. . Journal of Child Psychology and Psychiatry, vol. 30 (1).

19. Hodges, J. and Tizard, B. (1989b). "IQ and Behavioural Adjustment Of Ex-Institutional Adolescents. Journal of Child Psychology and Psychiatry, vol. 30 (1).

20. Hodgkin, R. and Newel, P., (Ed.) (1998). Unicef Çocuk Haklarına Dair Sözleşme Uygulama El Kitabı. Birleşmiş Milletler Çocuk Fonu. Ankara: Ajans-Türk Basın ve Basım A.Ş.

21. Hortaçsu, N. (2007). "Ben ve Biz: Benlik ve Kimlik". Ben Biz Siz Hepimiz Toplumsal Kimlik ve Gruplararası İlişkiler. Ankara: İmge Kitabevi.

22. Kağıtçıbaşı, Ç., (2000). Kültürel Psikoloji. "Kültür Bağlamında İnsan ve Aile." Sosyal Psikoloji Dizisi:2. 2. Basım. İstanbul: Evrim Yayınları.

23. Koşar, N., (1992). "Kurum Bakım Hizmeti". Sosyal Hizmetlerde Aile ve Çocuk Refahı Alanı. 2. Baskı. Ankara: MN Ofset

24. Malet, F.M., Mcsherry, D., Larkin, E., Kelly, G., Robinson, C., and Schubotz, D., (2010). Young Children Returning Home From Care: The Birth Parents' Perspective. Child \&Family Social Work. Vol.15, (1) ss:77-86 
25. Simsek, Z., Erol, N., Öztop, D. ve Münir, K., (2007). Prevalence and Predictors of Emotional and Behavioral Problems Reported by Teachers Among İnstitutionally Reared Children and Adolescents in Turkish Orphanages Compared with Community Controls. Children and Youth Services Review, Volume 29, Issue 7, ss:823-972.

26. Şimşek Z., Erol N., Öztop, D. ve Özcan, Ö., (2008). Kurum bakımı: Çocuk ve Gençlerde Davranış ve Duygusal Sorunların

Epidemiyolojisi; Ulusal Örneklemde Karşılaştırmalı bir Araştırma. Türk Psikiyatri Dergisi, 19(3), ss:235-246

27. Sosyal Hizmetler Çocuk Esirgeme Kanunu, (2002). Sosyal Hizmetler ve Çocuk Esirgeme Kurumu Mevzuatı. Sayı:39 Ankara: T.C.

Başbakanlık Sosyal Hizmetler ve Çocuk Esirgeme Kurumu Yayınları.

28. Stocker, C., Burwell, R., and Briggs, M., (2002). Sibling Conflict in Middle Childhood Predicts Children's Adjustment in Early Adolescence. Journal of Family Psychology. 16, ss:50-57.

29. Tucker, C., Barber, B., and Eccles, J., (1997). Advice About Life Plans and Personal Problems in Late Adolescent Sibling Relationships. Journal of Youth and Adolescence. 26, ss:63-76.

30. Tucker, C. Mchale, S., and Crouter, A., (2001). Conditions of Sibling Support in Adolescence. Journal of Family Psychology. 15, Ss:254-271.

31. Üstün, E., (2004). 8-12 Yaşları Arasındaki Korunmaya Muhtaç Çocukların Algısı. Çocuk Gelişimi ve Eğitimi Dergisi. Cilt:1, Sayı:10-11, ss:1-5

32. Üstüner, S., Erol, N. Ve Şimşek, Z., (2005). Koruyucu Aile Bakımı Altındaki Çocukların Davranış ve Duygusal Sorunları. Çocuk ve Gençlik Ruh Sağlığı Dergisi: 12 (3), 130-140.

33. Wolf, S., (2004) (çev. A.Oral- S.Kara). Problem Çocuklar " Stres Altındaki Çocukları Tedavi Etme Yöntemleri". 6. Basım. İstanbul: Say Yayınları.

34. Woodward, L.J. and Fergusson, D.M., (2000). Childhood Peer Relationship Problems and Later Risks of Educational

Underachievement and Unemployment. Journal of Child Psychology and Psychiatry and Allied Disciplines, 41 (2), 191-201

35. Yavuzer, H., (1993). "Aile ve Okul". Çocuk ve Suç. Ankara: Remzi Kitabevi.

36. Yılmaz, A., (2001). Eşler Arasındaki Uyum: Kuramsal Yaklaşımlar ve Görgül Çalışmalar. Aile ve Toplum Dergisi.1 (4);49-58. Ankara: T.C. Başbakanlık Aile Araştırma Kurumu Başkanlığı Yayınları.

37. Yörükoğlu, A., (1989). Değişen Toplumda Aile ve Çocuk. 3. Baskı. İstanbul: Özgür Yayın-Dağıtım.

38. Zocolillo, M., Pickles, A., Quinton, D., and Rutter, M., (1992). The outcome of childhood conduct disorder:Implication for defining adult personality disorder and conduct disorder. Psychological Medicine, 22, ss:971-986.

39. wWw.shcek.gov.tr (Erişim: Şubat 2010)

40. Www.cocukhizmetleri.gov.tr (Erişim: Nisan 2014) 